\title{
Phylogenetic analysis of strains of Orf virus isolated from two outbreaks of the disease in sheep in Greece
}

\author{
Charalambos Billinis ${ }^{1}$, Vasia S Mavrogianni ${ }^{1}$, Vasiliki Spyrou ${ }^{2}$ and George C Fthenakis ${ }^{1 *}$
}

\begin{abstract}
Background: Although orf is endemic around the world, there are few descriptions of Orf virus strains and comparisons of these strains. We report the sequence and phylogenetic analysis of the partial B2L gene of Orf virus from two outbreaks of the disease in Greece. The first was an outbreak of genital form of the disease in a flock imported from France, whilst the second was an outbreak of the disease in the udder skin of ewes and around the mouth of lambs in an indigenous flock.

Results: Phylogenetic analysis was performed on a part (498 bp) of the B2L gene of 35 Parapoxvirus isolates, including the two Orf virus isolates recovered from each of the two outbreaks in the present study. This analysis revealed that the maximum nucleotide and amino-acid variation amongst Orf virus strains worldwide $(n=33)$ was $8.1 \%$ and $9.6 \%$, respectively. The homology of the nucleotide and amino-acid sequences between the two Greek isolates was $99.0 \%$ and $98.8 \%$, respectively. The two Greek isolates clustered only with Orf virus strains.

Conclusions: We suggest that there can be differences between strains based on their geographical origin. However, differences in the origin of strains or in the clinical presentation of the disease may not be associated with their pathogenicity. More work is required to determine if differing clinical presentations are linked to viral strain differences or if other factors, e.g., flock immunity, method of exposure or genetic susceptibility, are more important to determine the clinical presentation of the infection.
\end{abstract}

Keywords: Contagious ecthyma, Genital orf, Greece, Mastitis, Orf, Phylogenetic analysis, Sheep, Teat

\section{Background}

Contagious echtyma ('orf') is a contagious disease, caused by the epitheliotropic Orf virus, a member of the genus Parapoxvirus. The disease has a worldwide distribution and a significant financial importance. The disease affects primarily sheep and goats; camels, South American camelids, Cervidae (deer, reindeer), other ruminants (bighorn sheep, chamois, dall sheep, mountain goats, musk oxen, serows, steenboks, tahr), dogs, cats and squirrels. The disease also has a zoonotic potential, although it is more of an occupational hazard to people working with animals (e.g., farmers, animal carers, veterinarians).

Clinical features of the infection vary. In some animals, infection may remain subclinical; however, occasionally

\footnotetext{
* Correspondence: gcf@vet.uth.gr

${ }^{1}$ Veterinary Faculty, University of Thessaly, Karditsa, Greece

Full list of author information is available at the end of the article
}

and especially in young animals, case fatality may reach up to $80 \%$ [1]. In lambs, lesions are usually localised around the mouth and the nostrils, frequently originating at the commissures of the lips; lesions can also be seen within the buccal cavity (gums, hard palate, tongue) and, occasionally, in the oesophagus or the abomasum. In ewes, lesions are primarily observed on the teat (usually, around the teat orifice) or the udder skin and less often in the inguinal area and the thigh [2]. In adult animals, lesions of the disease can also be found in the genital organs (ewes: vulva and skin-vaginal junction, rams: preputial orifice) [3], as well as in the coronet [4]. Lesions follow a well-defined development pattern: local erythema, followed by formation of papules, vesicles, postules and scabs. As lesions resolve, scabs become dry and are shed, with no scar remaining at the lesion site.

\section{Biomed Central}

(c) 2012 Billinis et al; licensee BioMed Central Ltd. This is an Open Access article distributed under the terms of the Creative Commons Attribution License (http://creativecommons.org/licenses/by/2.0), which permits unrestricted use, distribution, and reproduction in any medium, provided the original work is properly cited. 
The virus genome includes linear double-stranded DNA. The envelope gene (B2L) of the virus encodes a highly immunogenic major envelope protein of molecular weight about $42 \mathrm{kDa}$ [5]. This gene has been widely used for molecular characterisation and phylogenetic analysis of strains of the virus [6-9].

Although the disease is endemic around the world, there are few descriptions of Orf virus strains and comparisons of these strains between them. Details of 31 Orf virus strains, whose sequence of the envelope gene (B2L) has been reported before and which were used in the present study, are presented in Table 1. Of these strains, only five (one each from sheep, goats, reindeer, chamois and mountain goats) had been isolated in Europe. All strains had been isolated from skin lesion form of the disease.

In this paper, we report the sequence and phylogenetic analysis of the B2L gene of Orf virus from two outbreaks of the disease in Greece. The first was an outbreak of the genital form of the disease in a flock imported from France, whilst the second was an outbreak of the disease in the udder skin of ewes and around the mouth of lambs in an indigenous flock. This is the first information comparing Orf virus strains isolated in Greece and their relationship with strains isolated in other parts of the world based on B2L gene. This is also the first information regarding an Orf virus strain isolated from the genital form of the disease.

\section{Case presentation}

The first outbreak occurred in 2003 and involved cases of genital form of orf. It was recorded in an intensive dairy flock with 115 Lacaune-breed ewes, in the region of Peloponnese in South Greece (coordinates: $37.06^{\circ} \mathrm{N}, 21.63^{\circ} \mathrm{E}$ ). Animals in the flock were imported from France after the end of the breeding season. Cases were diagnosed 2 months after the end of the mating season, soon after establishment of the animals in the farm. Clinically, lesions characteristic of orf (papules, postules and scabs) were recorded in 78 ewes. Lesions were localised in the lower part of the vulva and the entrance of the vagina (Figure 1a); their removal was followed by mild bleeding. In 10 ewes, purulent vaginal discharge was evident (Figure 1b). The lesions progressively resolved and, subsequently, all ewes lambed normally. After lambing, cases of orf were detected in the teats of 24 ewes of those previously affected, as well as around the lips and the nostrils of their lambs. No cases of the disease were recorded in the farm staff.

The second outbreak occurred in 2004 and involved cases of orf in the teats of ewes and around the lips and the nostrils of their lambs in an indigenous semi-intensive dairy flock with 220 Karagouniko-breed ewes, in the region of Thessaly in Central Greece (coordinates: 39.39 ${ }^{\circ} \mathrm{N}, 21.94{ }^{\circ} \mathrm{E}$ ). The famer reported that outbreaks of the disease had been occurring in the flock for some years. Clinical cases with lesions characteristic of orf (papules, postules and scabs) were recorded post-partum in 18 lactating ewes and in their lambs. In ewes, lesions were localised in the body of the teats and around the teat orifice (Figure 2a); in lambs, lesions were localised in the corners of the lips (Figure. 2b). All cases, in ewes and lambs, recovered spontaneously. No cases of the disease were recorded in the farm staff.

In both outbreaks, a tentative clinical diagnosis of orf was made on clinical evidence. Material was collected and submitted for virological examination from 25 animals (genital system and teats) in the first farm and from all affected ewes ( $\mathrm{n}=18$; teats) and 10 lambs (lips) in the second farm. In each case, scabs formed over the lesions (2-3 scabs from each animal) were collected and transferred to the laboratory within $24 \mathrm{~h} ; 10 \%$ suspension in PBS, pH 7.2 was prepared.

DNA was isolated from the suspension, by using a commercial kit (Gentra Systems, Minneapolis, USA), according to the manufacturer's instructions. PCR amplification was carried out according to the guidelines described by Kwok and Higuchi [20]. The sequence of the primers and the PCR conditions to amplify a part of $594 \mathrm{bp}$ of B2L gene of Orf virus, were the same as previously described [6] with slight modifications. More specifically, the Invitrogen PCR selection kit (Invitrogen, Carlsbad, CA, USA) was used. Each reaction mixture (total volume: $25 \mu \mathrm{L}$ ) contained $5 \mu \mathrm{L} 1 \times$ buffer, $1.5 \mathrm{mM}$ $\mathrm{MgCl}_{2}, 1 \mu \mathrm{L}$ deoxynucleoside triphosphate mix (final concentration of each dNTP: 0,2 mM), 0,2 $\mu \mathrm{L}$ Platinum Taq DNA polymerase, 100 ng of extracted DNA and 25 pmoles of the primers PPP-1 5'-gtc gtc cac gat gag gag ct-3' and PPP-4 5'-tac gtg gga agc gcc tcg ct-3' (based on the previously published sequence of the B2L gene of Orf virus strain NZ2/2004 [12]). Following an initial denaturation for $2 \mathrm{~min}$ at $94^{\circ} \mathrm{C}$, the reaction mixture was subjected to 35 cycles of heat denaturation at $94^{\circ} \mathrm{C}$ for $35 \mathrm{~s}$, primer annealing at $60^{\circ} \mathrm{C}$ for $35 \mathrm{~s}$ and DNA extension at $72^{\circ} \mathrm{C}$ for $45 \mathrm{~s}$, completed by a final extension of $5 \mathrm{~min}$ at $72^{\circ} \mathrm{C}$.

Following amplification, $10 \mu \mathrm{L}$ of each PCR product was analysed by electrophoresis on $2 \%$ agarose gel and stained with ethidium bromide $\left(0.5 \mathrm{mg} \mathrm{mL}^{-1}\right)$. A $100 \mathrm{bp}$ DNA ladder was analysed on the same gel to serve as a size marker. As negative control, DEPC-treated $\mathrm{H}_{2} \mathrm{O}$ was used instead of DNA in PCR assay, to exclude any contamination. The positive PCR products were purified by using the PureLink PCR Purification Kit (Invitrogen, Carlsbad, CA, USA) according to the manufacturers' instructions. Sequence analysis in both directions was performed commercially by MWG Biotech (Ebersberg, Germany). All samples were analysed twice and only high-quality sequences were used. 
Table 1 Information about Parapoxvirus strains $(n=35)$ used for phylogenetic analysis

\begin{tabular}{|c|c|c|c|c|c|}
\hline No & Strain identification & Animal species infected & Country of origin & GenBank accession no. & Reference \\
\hline 1 & Cro-Cres-12446/09 & Sheep & Croatia & HQ215589 & {$[10]$} \\
\hline 2 & Vaccine strain & Goat & USA & AY278209 & [11] \\
\hline 3 & Ena & Serow & Japan & AB521175 & {$[6]$} \\
\hline 4 & $\mathrm{NZ2/2004}$ & Sheep & New Zealand & AY453667 & [12] \\
\hline 5 & $\mathrm{His}$ & Sheep & Japan & AB189670 & [13] \\
\hline 6 & MTO5 & Sheep & Brazil & FJ665818 & {$[7]$} \\
\hline 7 & Hoping & Goat & Taiwan & EU935106 & {$[14]$} \\
\hline 8 & Cro-Goat-11727/10 & Goat & Croatia & HQ215588 & [10] \\
\hline 9 & Hub/2009 & Goat & China & GU320351 & [9] \\
\hline 10 & GRE-1 genital 2003 & Sheep & Greece & JN368482 & Present study \\
\hline 11 & GRE-2 teat 2004 & Sheep & Greece & JN368483 & Present study \\
\hline 12 & NE1 & Goat & Brazil & FJ665819 & [7] \\
\hline 13 & Taiping & Goat & Taiwan & EU327506 & {$[14]$} \\
\hline 14 & ORFV/2009/Korea & Goat & Korea & GQ328006 & {$[8]$} \\
\hline 15 & [unidentified] & [unknown] & Iran & AY958203* & [Ghorashi et al. (unpublished)] \\
\hline 16 & Jilin & Sheep & China & FJ808074 & {$[15]$} \\
\hline 17 & India 67/04 & Sheep & India & DQ263305 & [16] \\
\hline 18 & Pseudocowpox virus strain & Cattle & - & AY424972 & [11] \\
\hline 19 & F00.120R & Reindeer & Finland & AY453656 & [12] \\
\hline 20 & Bovine papular stomatitis virus strain & Cattle & - & AY424973 & {$[11]$} \\
\hline 21 & Assam09 & Goat & India & JN846834* & [Bora et al. (unpublished)] \\
\hline 22 & ORFV/LiaoNing/2010/China & Goat & China & HQ694773* & [Zhang et al. (unpublished)] \\
\hline 23 & ORFV/GanSu/2009/China & Sheep & China & HQ694772* & [Zhang et al. (unpublished)] \\
\hline 24 & Isolate A & Goat & Brasil & JN088053* & [Abrahao et al. (unpublished)] \\
\hline 25 & Isolate D & Sheep & Brasil & JN088052* & [Abrahao et al. (unpublished)] \\
\hline 26 & Isolate A & Goat & Brasil & JN088051* & [Abrahao et al. (unpublished)] \\
\hline 27 & Shanxi & Goat & China & HQ202153* & [Shi (unpublished)] \\
\hline 28 & JSO4 & Sheep & China & GU903501 & {$[17]$} \\
\hline 29 & Cam/09 & Camel & India & GU460370* & [Venkatesan et al. (unpublished)] \\
\hline 30 & Muk/2000 & Goat & India & HM466933* & [Venkatesan et al. (unpublished)] \\
\hline 31 & GE & Serow & Japan & AB493826 & {$[18]$} \\
\hline 32 & Asahi & Serow & Japan & AB521170 & [19] \\
\hline 33 & $485 / 09$ & Chamois & Italy & HQ239073* & [Scagliarini et al. (unpublished)] \\
\hline 34 & $378 / 08$ & Mountain goat & Italy & HQ239072* & [Scagliarini et al. (unpublished)] \\
\hline 35 & NZ-2/1994 & Sheep & New Zealand & OVU06671 & {$[5]$} \\
\hline
\end{tabular}

Strains 1-17, 19 \& 21-35: Orf virus, *: information regarding this strain drawn through GenBank accession no.

Extracted DNA from material submitted and examined from all animals, from both flocks was positive for Orf virus. From both outbreak 1 and outbreak 2, all isolates within each outbreak were identical based on the analysis of part of B2L gene. However, different isolates were recovered from each of the two outbreaks. We designated the isolates by the codes 'GRE-1 genital 2003' (recovered from the first outbreak, i.e., from cases of genital form of orf) and 'GRE-2 teat 2004' (recovered from the second outbreak, i.e., from cases of orf in the teats of ewes and around the lips and the nostrils of their lambs).
The partial sequence of the major envelope gene of the two strains of Orf virus, i.e. 'GRE-1 genital 2003' and 'GRE-2 teat 2004', were submitted to GenBank with accession numbers JN368482 and JN368483, respectively. Nucleotide sequences from other Parapoxvirus isolates were retrieved from Genbank (NCBI). Phylogenetic and molecular evolutionary analyses were conducted using program MEGA 3.1 [21]. A neighbour-joining phylogenetic tree using Kimura-2 parameter distance matrix [22] was inferred from sequence of 35 Parapoxvirus strains; these included a Bovine papular stomatitis virus strain, 


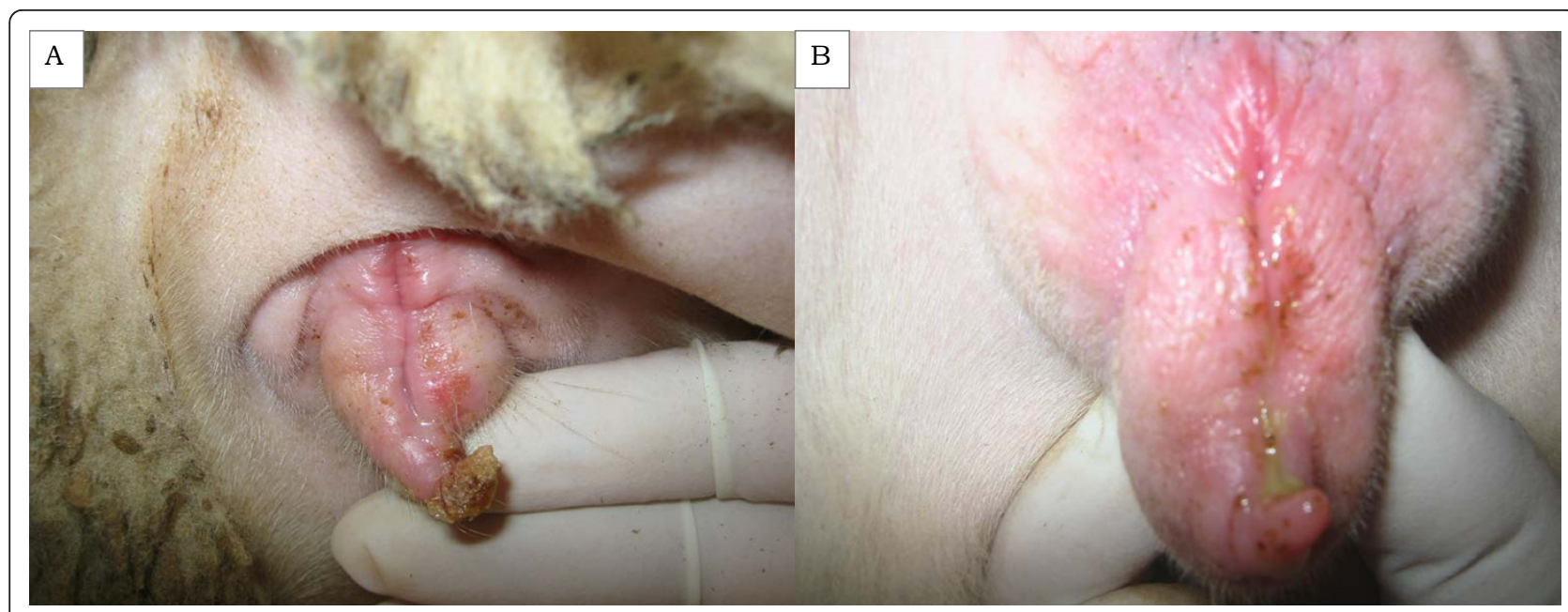

Figure 1 Representative lesions of genital form of orf in ewes. (a) Orf scabs scattered in the lower part of the vulva and the entrance of the vagina of a ewe. (b) Purulent vaginal discharge in a ewe with genital form of orf.

Pseudocowpox virus strain, 31 Orf virus strains previously isolated by other researchers and the two strains isolated in the present study (Figure. 3). Node support was assessed with 1,000 bootstrap pseudo-replicates. Detailed information of Parapoxvirus strains analysed is in Table 1.

Phylogenetic analysis was performed on a part (498 bp) of B2L gene 35 Parapoxvirus strains, including the two strains recovered in the present study. This analysis revealed that the maximum nucleotide and amino-acid variation amongst Orf virus strains isolates worldwide ( $\mathrm{n}$ = 33) was $8.1 \%$ and $9.6 \%$, respectively. The homology of the nucleotide and amino-acid sequences between the two Greek isolates was $99.0 \%$ and $98.8 \%$, respectively. The two Greek isolates clustered only with Orf virus strains (Figure 3).
The 'GRE-1 genital 2003' Orf virus strain (isolated from cases of genital form of orf) clustered together with the following strains: Cro-Cres 12446/09 from Croatia, Vaccine strain from USA, Ena, HIS, GE and Asahi from Japan from Japan, NZ2/2004 from New Zealand, MTO5 and Isolate A from Brazil, and 485/09 and 373/08 from Italy. It shared the highest homology with Cro Cres 12446/09 (99.6\% homology) at nucleotide level and with Cro-Cres 12446/09, Ena, His, GE, Asahi, NZ2/2004, MTO5, 485/09 and 373/08 (100\% homology) at amino-acid level.

The 'GRE-2 teat 2004' Orf virus strain (isolated from cases of orf in the teats of ewes and around the lips and the nostrils of their lambs) clustered together with the following strains: Hoping and Taiping from Taiwan, Cro-Goat 11727/10 from Croatia, Hub/2009 and ORFV/

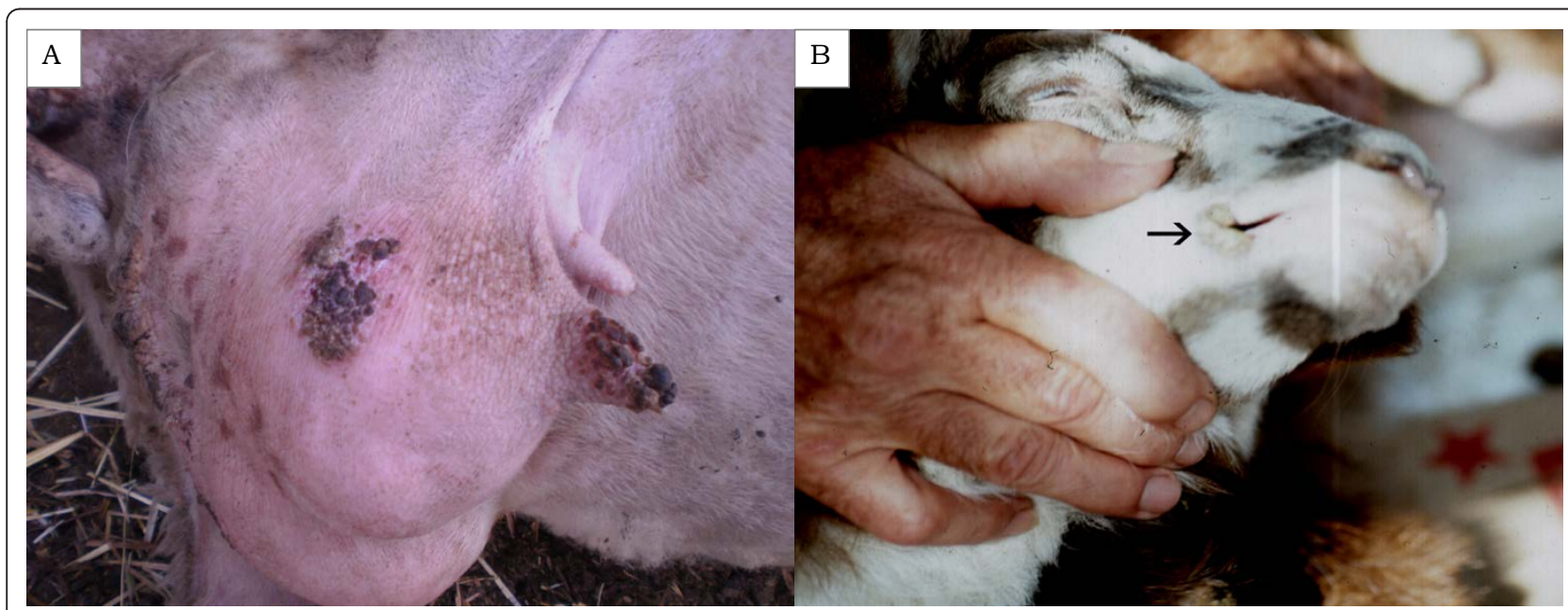

Figure 2 Representative lesions of orf in the teats of ewes and around the lips and the nostrils of their lambs. (a) Orf scabs in the body of a teat and the skin of the udder of a ewe. (b) Orf lesions in the commissures of the lips of a lamb. 


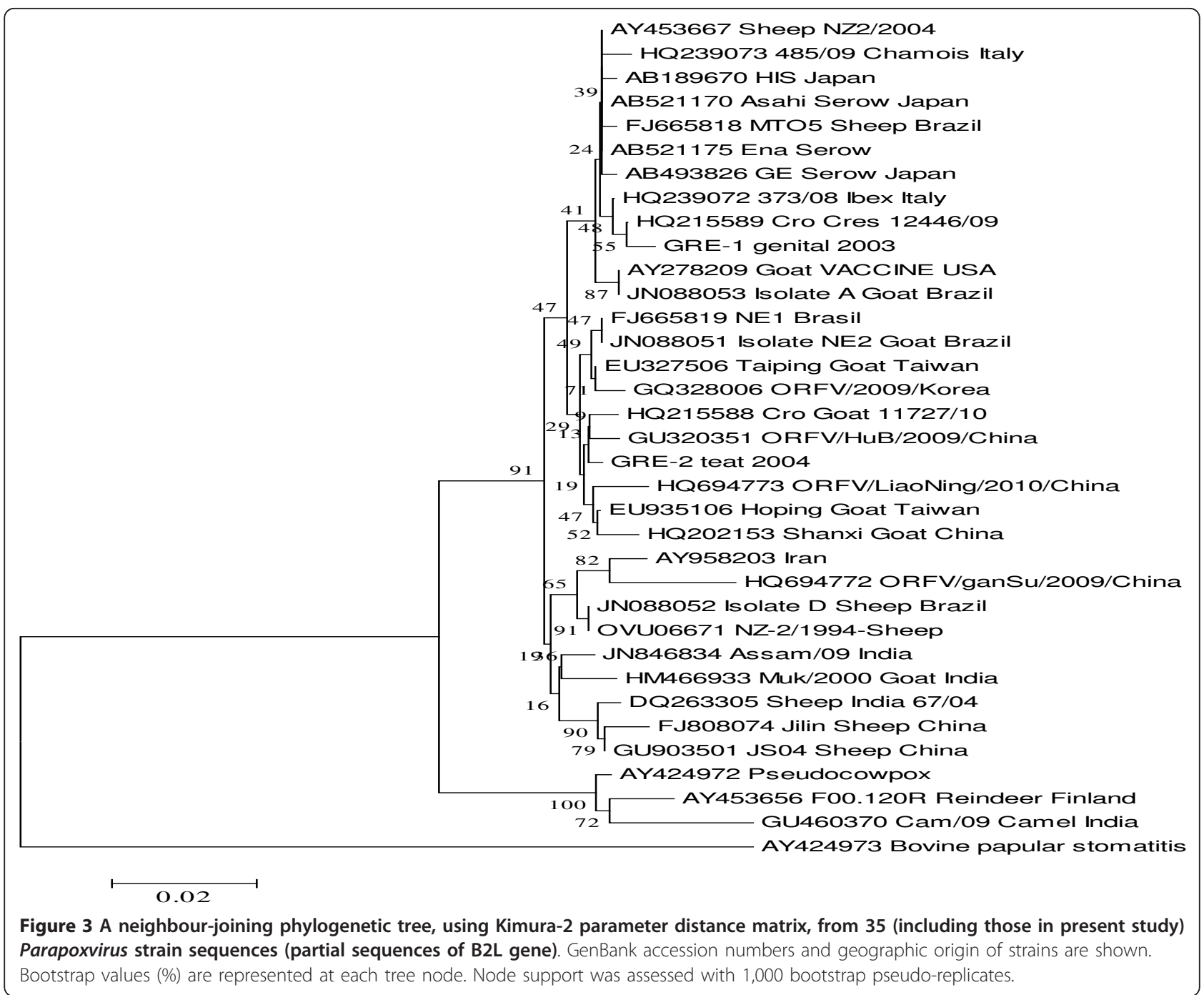

LiaoNing/2010/China from China, NE1 from Brazil and ORFV/2009/Korea from Korea. It shared the highest homology with NE1 (99.6\% homology) at nucleotide level and with Hoping, Cro-Goat 11727/10, Hub/2009 and Shanxi (100\% homology) at amino-acid level.

The percent diversity of the nucleotide sequence of the partial B2L gene between the 33 Orf virus strains is shown in Table 2, whilst alignment of nucleotide sequences of the B2L gene from 7 (including those in the present study) Orf Virus strains is shown in Figure. 4.

\section{Discussion}

There are few reports of characterisation of Orf virus strains by using the B2L gene, from world-wide sources, with only five of the strains described isolated in Europe prior to this study. All strains have been isolated from the udder skin of ewes or from lambs. This is the first genetic characterisation of a strain from the genital form of the disease. In a previous phylogenetic analysis of Orf virus strains from Greece and Italy [23], the VIR gene of the virus was amplified; hence the results are not comparable to the present ones.

Reports of the genital form of the disease in ewes are limited to the description of the skin lesions. Vaginitis (as indicated by the purulent discharge from the animals; Figure. 1b) has never been reported. However, in all cases, pregnancy was carried to term in all affected animals. In the second outbreak, animals from the flock infected with the 'GRE-2 teat 2004' strain were subsequently used in an experimental study, where it was shown that Orf virus infection in teats of ewes leads to depletion of local mammary defences and predisposes animals to mastitis [24]. Those experimental findings were allied to the clinical evidence recorded in the same farm, where higher frequency of mastitis was recorded among the Orf virusinfected animals [25].

One may suggest that there can be differences between strains based on their origin (one strain isolated 
Table 2 Percent nucleotide sequence diversity of the partial B2L gene between 35 Parapoxvirus strains

\section{Strain no.}

\begin{tabular}{|c|c|c|c|c|c|c|c|c|c|c|c|c|c|c|c|c|c|c|c|c|c|c|c|c|c|c|c|c|c|c|c|c|c|c|}
\hline $\begin{array}{l}\text { Strain no.-GenBank } \\
\text { accession no. }\end{array}$ & 1 & 2 & 3 & 4 & 5 & 6 & 7 & 8 & 9 & 10 & 11 & 12 & 13 & 14 & 15 & 16 & 17 & 18 & 19 & 20 & 21 & 22 & 23 & 24 & 25 & 26 & 27 & 28 & 29 & 30 & 31 & 32 & 333 & $34 \quad 35$ \\
\hline \multicolumn{35}{|l|}{ 01-HQ215589 } \\
\hline 02-JN368482 & 0.4 & & & & & & & & & & & & & & & & & & & & & & & & & & & & & & & & & \\
\hline 03-HQ215588 & 1.6 & 1.2 & & & & & & & & & & & & & & & & & & & & & & & & & & & & & & & & \\
\hline 04-FJ808074 & 2.7 & 3.1 & 2.7 & & & & & & & & & & & & & & & & & & & & & & & & & & & & & & & \\
\hline 05-DQ263305 & 2.3 & 2.7 & 2.3 & 1 & & & & & & & & & & & & & & & & & & & & & & & & & & & & & & \\
\hline 06-AY424973 & 18.3 & 18.3 & 18.3 & 19.1 & 18.6 & & & & & & & & & & & & & & & & & & & & & & & & & & & & & \\
\hline 07-AY424972 & 5.4 & 5.4 & 5 & 4.6 & 3.9 & 18.3 & & & & & & & & & & & & & & & & & & & & & & & & & & & & \\
\hline 08-EU935106 & 1.2 & 1.6 & 0.8 & 2.3 & 1.8 & 18.1 & 5 & & & & & & & & & & & & & & & & & & & & & & & & & & & \\
\hline 09-GU320351 & 1.6 & 1.6 & 0.8 & 2.7 & 2.3 & 18.3 & 5 & 0.8 & & & & & & & & & & & & & & & & & & & & & & & & & & \\
\hline 10-FJ665819 & 1.4 & 1.4 & 0.6 & 2 & 1.6 & 17.6 & 4.3 & 0.6 & 0.6 & & & & & & & & & & & & & & & & & & & & & & & & & \\
\hline 11-EU327506 & 1.2 & 1.2 & 0.8 & 2.3 & 1.8 & 17.6 & 4.6 & 0.8 & 0.8 & 0.2 & & & & & & & & & & & & & & & & & & & & & & & & \\
\hline $12-F J 665818$ & 0.6 & 1 & 1.4 & 2.5 & 2 & 18.3 & 5.2 & 1 & 1.4 & 1.2 & 1 & & & & & & & & & & & & & & & & & & & & & & & \\
\hline 13-AY278209 & 0.8 & 1.2 & 1.6 & 2.2 & 1.8 & 18.3 & 5 & 1.2 & 1.6 & 1.4 & 1.2 & 0.6 & & & & & & & & & & & & & & & & & & & & & & \\
\hline 14-JN368483 & 1 & 1 & 0.6 & 2.5 & 2 & 17.8 & 4.8 & 0.6 & 0.6 & 0.4 & 0.6 & 1.2 & 1.4 & & & & & & & & & & & & & & & & & & & & & \\
\hline 15-GQ328006 & 1.6 & 1.6 & 1.2 & 2.7 & 2.2 & 17.8 & 5 & 1.2 & 1.2 & 0.6 & 0.4 & 1.4 & 1.6 & 1 & & & & & & & & & & & & & & & & & & & & \\
\hline 16-AY958203 & 2.5 & 2.9 & 2.9 & 2.5 & 1.8 & 19.1 & 4.6 & 2.5 & 2.9 & 2.3 & 2 & 2.3 & 1.8 & 2.7 & 2.5 & & & & & & & & & & & & & & & & & & & \\
\hline 17-AY453656 & 6.3 & 6.3 & 5.9 & 5.4 & 4.8 & 19.1 & 1.2 & 5.9 & 5.9 & 5.2 & 5.4 & 6.1 & 5.9 & 5.6 & 5.8 & 5.4 & & & & & & & & & & & & & & & & & & \\
\hline 18-AY453667 & 0.4 & 0.8 & 1.2 & 2.3 & 1.8 & 18.1 & 5 & 0.8 & 1.2 & 1 & 0.8 & 0.2 & 0.4 & 1 & 1.2 & 2 & 5.9 & & & & & & & & & & & & & & & & & \\
\hline 19-AB521175 & 0.4 & 0.8 & 1.2 & 2.3 & 1.8 & 18.1 & 5 & 0.8 & 1.2 & 1 & 0.8 & 0.2 & 0.4 & 1 & 1.2 & 2 & 5.9 & 0 & & & & & & & & & & & & & & & & \\
\hline 20-AB189670 & 0.6 & 1 & 1.4 & 2.5 & 2 & 18.3 & 5.2 & 1 & 1.4 & 1.2 & 1 & 0.4 & 0.6 & 1.2 & 1.4 & 2.3 & 6.1 & 0.2 & 0.2 & & & & & & & & & & & & & & & \\
\hline 21-JN846834 & 1.8 & 1,8 & 1.8 & 1.6 & 1.4 & 18.3 & 4.1 & 1.8 & 1.8 & 1.6 & 1.4 & 1.6 & 1.4 & 1.6 & 1.8 & 2 & 5 & 1.4 & 1.4 & 1.6 & & & & & & & & & & & & & & \\
\hline 22-HQ694773 & 2 & 2 & 1.2 & 3.1 & 2.7 & 18.1 & 5.4 & 0.8 & 1.2 & 1 & 1.2 & 1.8 & 2 & 1 & 1.6 & 3.3 & 6.3 & 1.6 & 1.6 & 1.8 & 2.3 & & & & & & & & & & & & & \\
\hline 23-HQ694772 & 3.7 & 4.2 & 4.2 & 3.5 & 3.3 & 20.7 & 6.1 & 3.7 & 4.2 & 3.5 & 3.3 & 3.1 & 3.3 & 3.9 & 3.7 & 2.3 & 7 & 3.3 & 3.3 & 3.5 & 2.7 & 4.4 & & & & & & & & & & & & \\
\hline 24-JN088053 & 0.8 & 1.2 & 1.6 & 2.2 & 1.8 & 18.3 & 5 & 1.2 & 1.6 & 1.4 & 1.2 & 0.6 & 0 & 1.4 & 1.6 & 1.8 & 5.9 & 0.4 & 0.4 & 0.6 & 1.4 & 2 & 3.3 & & & & & & & & & & & \\
\hline 25-JN088052 & 1.4 & 1.8 & 2.2 & 1.6 & 1.4 & 18.6 & 4.3 & 1.8 & 2.2 & 1.6 & 1.4 & 1.2 & 1 & 2 & 1.8 & 1.2 & 5.2 & 1 & 1 & 1.2 & 1.2 & 2.7 & 2.3 & 1 & & & & & & & & & & \\
\hline 26-JN088051 & 1.4 & 1.4 & 0.6 & 2 & 1.6 & 17.6 & 4.3 & 0.6 & 0.6 & 0 & 0.2 & 1.2 & 1.4 & 0.4 & 0.6 & 2.3 & 5.2 & 1 & 1 & 1.2 & 1.6 & 1 & 3.5 & 1.4 & 1.6 & & & & & & & & & \\
\hline 27-HQ202153 & 1.4 & 1.6 & 1.2 & 2.9 & 2.5 & 18.9 & 5.6 & 0.6 & 1.4 & 1.2 & 1.4 & 1.6 & 1.8 & 1.2 & 1.8 & 3.1 & 6.5 & 1.4 & 1.4 & 1.6 & 2.5 & 1.4 & 4.4 & 1.8 & 2.5 & 1.2 & & & & & & & & \\
\hline 28-GU903501 & 2 & 2.5 & 2 & 0.6 & 0.4 & 18.6 & 3.9 & 1.6 & 2 & 1.4 & 1.6 & 1.8 & 1.6 & 1.8 & 2 & 1.8 & 4.8 & 1.6 & 1.6 & 1.8 & 1 & 2.5 & 2.9 & 1.6 & 1 & 1.4 & 2.2 & & & & & & & \\
\hline 29-GU460370 & 7.4 & 7.4 & 6.9 & 6.5 & 5.8 & 20.2 & 2.4 & 7 & 6.9 & 6.3 & 6.5 & 7.2 & 6.9 & 6.7 & 6.9 & 6.5 & 2.9 & 7 & 7 & 7.2 & 6.1 & 7.4 & 8.1 & 6.9 & 6.3 & 6.3 & 7.6 & 5.8 & & & & & & \\
\hline 30-HM466933 & 2.3 & 2.3 & 1.8 & 2 & 1.6 & 19.1 & 4.3 & 1.8 & 1.8 & 1.6 & 1.8 & 2 & 1.8 & 1.6 & 2.3 & 2.7 & 5.2 & 1.8 & 1.8 & 2 & 1.2 & 2.3 & 3.9 & 1.8 & 2 & 1.6 & 2.5 & 1.4 & 6.3 & & & & & \\
\hline 31-AB493826 & 0.6 & 1 & 1.4 & 2.5 & 2 & 18.3 & 5.2 & 1 & 1 & 1.2 & 1 & 0.4 & 0.6 & 1.2 & 1.4 & 2.2 & 6.1 & 0.2 & 0.2 & 0.4 & 1.6 & 1.8 & 3.5 & 0.6 & 1.2 & 1.2 & 1.6 & 1.8 & 7.2 & 2 & & & & \\
\hline $32-A B 521170$ & 0.4 & 0.8 & 1.2 & 2.3 & 1.8 & 18.1 & 5 & 0.8 & 1.2 & 1 & 0.8 & 0.2 & 0.4 & 1 & 1.2 & 2 & 5.9 & 0 & 0 & 0.2 & 1.4 & 1.6 & 3.3 & 0.4 & 1 & 1 & 1.4 & 1.6 & 7 & 1.8 & 0.2 & & & \\
\hline 33-HQ239073 & 0.8 & 1.2 & 1.4 & 2.7 & 2.3 & 18.6 & 5.4 & 1.2 & 1.6 & 1.4 & 1.2 & 0.6 & 0.8 & 1.4 & 1.6 & 2.5 & 6.3 & 0.4 & 0.4 & 0.6 & 1.8 & 2 & 3.7 & 0.8 & 1.4 & 1.4 & 1.8 & 2 & 7.4 & 2.3 & 0.6 & 0.4 & & \\
\hline 34-HQ239072 & 0.2 & 0.6 & 1.4 & 2.5 & 2 & 18.3 & 5.2 & 1 & 1.4 & 1.2 & 1 & 0.4 & 0.6 & 1.2 & 1.4 & 2.3 & 6.1 & 0.2 & 0.2 & 0.4 & 1.6 & 1.8 & 3.5 & 0.6 & 1.2 & 1.2 & 1.2 & 1.8 & 7.2 & 2 & 0.4 & 0.2 & 0.6 & \\
\hline 35-OVU06671 & 1.4 & 1.8 & 2.2 & 1.6 & 1.4 & 18.6 & 4.3 & 1.8 & 2.2 & 1.6 & 1.4 & 1.2 & 1 & 2 & 1.8 & 1.2 & 5.2 & 1 & 1 & 1.2 & 1.2 & 2.7 & 2.3 & 1 & 0 & 1.6 & 2.5 & 1 & 6.3 & 2 & 1.2 & 1 & 1.41 & 1.2 \\
\hline
\end{tabular}

Strains 1-5 \& 8-35: Orf virus, strain 6: Bovine papular stomatitis virus, strain 7: Pseudocowpox virus 


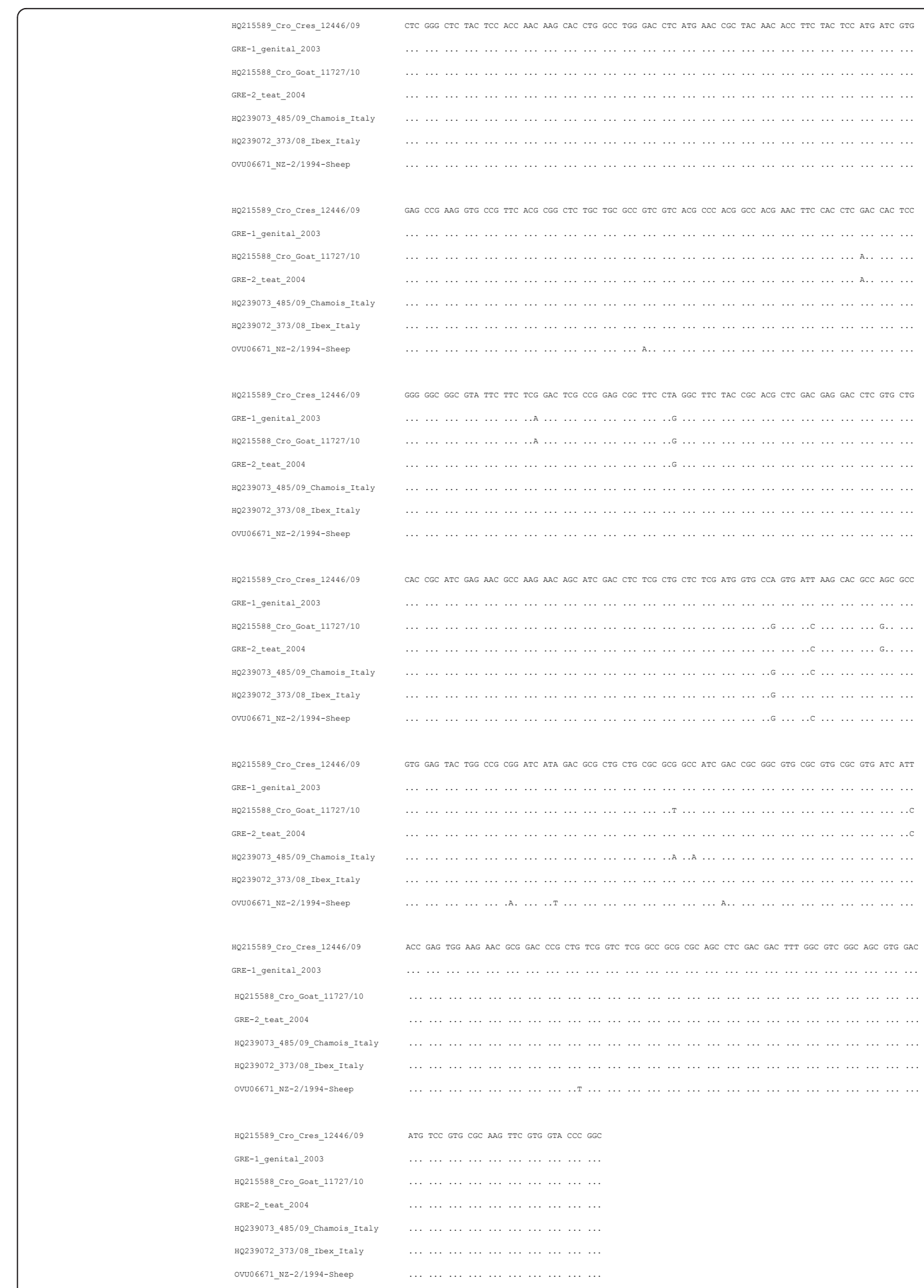

Figure 4 Alignment of 498 nucleotide sequences of the B2L gene from 7 (including those in the present study) Orf Virus strains Identical nucleotides within the sequence are marked by dots.

from animals imported from France, the other strain isolated from indigenous animals). Unfortunately, we could not find reports in the literature with genetic characterisation of Orf virus strains from France, which could have been used to compare with those of strain 'GRE-1 genital 2003'. Lojkic et al. [10] have also postulated that import of animals to their country (Croatia) has led to import of Orf virus strains in there. The 
genital form of the disease indicates a venereal transmission from the rams in France, before animals were transported to Greece. As the virus can persistently infect animals, one may suggest that the imported sheep had already been subclinically infected and the coupled transportation stress - pregnancy immunosuppression led to development of clinical disease.

\section{Conclusions}

No previous reports characterising Orf virus strains from the genital form of the disease exist. Hence, it will be interesting to study relationship of strains from different clinical entities of the disease. Based on current evidence, one may suggest that difference between strains did not seem to be associated with differing clinical signs, as animals with the genital form of the disease (first outbreak) subsequently developed lesions in their teats. Perhaps, differences in B2L gene may not reflect differences in clinical disease caused by the strains. Moreover, differences in the origin of strains may not be associated with their pathogenicity. In further support of that, it is noteworthy that a New Zealand strain is used in a vaccine to protect against the disease, which is licenced and widely used in European countries [1]. More work is required to determine if differing clinical presentations are linked to viral strain differences or if other factors (e.g., flock immunity, method of exposure or genetic susceptibility) are more important to determine the clinical presentation of the infection.

\section{Abbreviations}

DNA: Deoxyribonucleic acid; dNTP: Deoxyribonucleotide; PBS: Hosphatebuffered saline; PCR: Polymerase chain reaction

\section{Author details}

${ }^{1}$ Veterinary Faculty, University of Thessaly, Karditsa, Greece. ${ }^{2}$ Department of Animal Production, Technological Educational Institute of Larissa, Larissa, Greece.

\section{Authors' contributions}

CB: virological studies and manuscript preparation; VSM: clinical work; VS: virological studies; GCF: clinical work and manuscript preparation. All authors read and approved the final manuscript.

\section{Competing interests}

The authors declare that they have no competing interests.

Received: 10 August 2011 Accepted: 19 January 2012

Published: 19 January 2012

\section{References}

1. Reid HW, Rodger SM: Orf. In Diseases of Sheep.. 4 edition. Edited by: Aitken Al. Oxford: Blackwell; 2007:297-306.

2. Nandi S, De Ujjwal K, Chowdhury S: Current status of contagious ecthyma or orf disease in goat and sheep -A global perspective. Small Rumin Res 2011, 96:73-82.

3. Gouletsou PG, Fthenakis GC: Clinical evaluation of reproductive ability of rams. Small Rumin Res 2010, 92:45-51.

4. Egerton JR: Diseases of the feet. In Diseases of Sheep.. 4 edition. Edited by: Aitken Al. Oxford: Blackwell; 2007:273-281.
5. Sullivan JT, Mercer AA, Fleming SB, Robinson AJ: Identification and characterization of an orf virus homologue of the vaccinia virus gene encoding the major envelope antigen p37K. Virology 1994, 202:968-973.

6. Inoshima Y, Morooka A, Sentsui H: Detection and diagnosis of parapoxvirus by the polymerase chain reaction. J Virol Methods 2000, 84:201-208.

7. Abrahão JS, Campos RK, Trindade GS, Guedes MI, Lobato Zl, Mazur C, Ferreira PC, Bonjardim CA, Kroon EG: Detection and phylogenetic analysis of Orf virus from sheep in Brazil: a case report. Virol J 2009, 6:47.

8. Oem JK, Roh IS, Lee KH, Lee KK, Kim HR, Jean YH, Lee OS: Phylogenetic analysis and characterization of Korean orf virus from dairy goats: case report. Virol J 2009, 6:167.

9. Zhang $K$, Shang $Y$, Jin $Y$, Wang G, Zheng H, He J, Lu Z, Liu X: Diagnosis and phylogenetic analysis of Orf virus from goats in China: a case report. Virol J 2010, 7:78.

10. Lojkic I, Cac Z, Beck A, Bedekovic T, Cvetnic Z, Sostaric B: Phylogenetic analysis of Croatian orf viruses isolated from sheep and goats. Virol J 2010, 7:314.

11. Guo J, Zhang Z, Edwards JF, Ermel RW, Taylor C Jr, de la ConchaBermejillo A: Characterization of a North American orf virus isolated from a goat with persistent, proliferative dermatitis. Virus Res 2033, 93:169-179.

12. Tikkanen MK, Mclnnes CJ, Mercer AA, Büttner M, Tuimala J, Hirvelä-Koski V, Neuvonen E, Huovilainen A: Recent isolates of parapoxvirus of Finnish reindeer (Rangifer tarandus tarandus) are closely related to bovine pseudocowpox virus. J Gen Virol 2004, 85:1413-1418.

13. Kanou Y, Inoshima Y, Shibahara T, Ishikawa Y, Kadota K, Ohashi S, Morioka K, Yoshida K, Yamada S: Isolation and characterization of a parapoxvirus from sheep with papular stomatitis. Jpn Agric Res Q 2005, 39:197-203.

14. Chan KW, Hsu WL, Wang CY, Yang CH, Lin FY, Chulakasian S, Wong ML: Differential diagnosis of orf viruses by a single-step PCR. J Virol Methods 2009, 160:85-89.

15. Zhao K, Song D, He W, Lu H, Zhang B, Li C, Chen K, Gao F: Identification and phylogenetic analysis of an Orf virus isolated from an outbreak in sheep in the Jilin province of China. Vet Microbiol 2010, 142:408-415.

16. Hosamani M, Bhanuprakash V, Scagliarini A, Singh R: Comparative sequence analysis of major envelope protein gene (B2L) of Indian orf viruses isolated from sheep and goats. Vet Microbiol 2006, 116:317-324.

17. Liu Y, Shao H, Cheng R: Establish and application of PCR detection method to contagious pustular dermatitis virus. Jilin Xu Mu Shou Yi 2007, 03:7-9.

18. Inoshima $Y$, Ito $M$, Ishiguro N: Spatial and temporal genetic homogeneity of orf viruses infecting Japanese serows (Capricornis crispus). J Vet Med Sci 2010, 72:701-707.

19. Inoshima Y, Murakami K, Wu D, Sentsui H: Characterization of parapoxviruses circulating among wild Japanese serows (Capricornis crispus). Microbiol Immunol 2002, 46:583-587.

20. Kwok S, Higuchi R: Avoiding false positives with PCR. Nature 1989, 339:237-238.

21. Kumar S, Tamura K, Nei M: MEGA3: Integrated software for molecular evolutionary genetics analysis and sequence alignment. Brief Bioinform 2004, 5:150-163.

22. Kimura M: A simple method for estimating evolutionary rates of base substitutions through comparative studies of nucleotide sequences. $J$ Molec Evol 1980, 16:111-120.

23. Kottaridi C, Nomikou K, Teodori L, Savini G, Lelli R, Markoulatos P, Mangana O: Phylogenetic correlation of Greek and Italian orf virus isolates based on VIR gene. Vet Microbio/ 2006, 116:310-316.

24. Mavrogianni VS, Cripps PJ, Papaioannou N, Taitzoglou I, Fthenakis GC: Teat disorders predispose ewes to clinical mastitis after challenge with Mannheimia haemolytica. Vet Res 2006, 37:89-105.

25. Mavrogianni VS, Fthenakis GC: Clinical, bacteriological, cytological and pathological features of teat disorders in ewes. J Vet Med A 2007, 54:219-223.

doi:10.1186/1743-422X-9-24

Cite this article as: Billinis et al:: Phylogenetic analysis of strains of Orf virus isolated from two outbreaks of the disease in sheep in Greece. Virology Journal 2012 9:24. 